\title{
Analisis kualitas website Dewan Perwakilan Mahasiswa Universitas Telkom menggunakan WebQual 4.0
}

\author{
Mochammad Faizal* \\ Magister Manajemen, Universitas Telkom \\ Jl. Telekomunikasi 1. Bandung. 40257. Indonesia \\ hai@mf-chan.com \\ *Penulis Korespondensi
}

Submitted: Dec 6, 2018; Reviewed:Dec 21, 2018; Accepted: Feb 1, 2019

\begin{abstract}
Telkom University is a tertiary institution that has a variety of student organizations as a place to channel and develop the potential of students. Student Council of Telkom University Student Family or commonly abbreviated as DPM Kema Tel-U is one of the student organizations at Telkom University that has several functions such as supervision, legislation, aspirations, and budget. The involvement of Telkom University students is needed in carrying out these four functions, and one of the methods used is to carry out publication activities related to various activities that will be or are being held. However, Kema Tel-U DPM has not been able to maximize the website which is considered to be the main channel in information dissemination activities. To answer these problems, researchers will conduct a literature study to obtain various relevant theories, modify the WebQual 4.0 instrument that is tailored to the research needs, then conduct questionnaires to 120 students of Telkom University. The collected data will be analyzed using the suitability level method and importance-performance analysis using the SPSS version 25 application to answer the research problem. This study aims to determine the level of user satisfaction with the DPM Kema Tel-U website, as well as identify variables that need to be addressed to improve the quality of research objects by their priorities. The results obtained are the priority order for improving a website maintained by the Student Representative Council of Telkom University, and a new instrument derived from modified WebQual instruments 4.0. This research can be a reference to assess other websites that are similar to the DPM Kema Tel-U website.
\end{abstract}

Keywords: importance performance analysis; students organization; students representative council; webqual 4.0; website

Abstrak: Universitas Telkom merupakan sebuah perguruan tinggi yang telah memiliki berbagai macam organisasi mahasiswa sebagai wadah untuk menyalurkan dan mengembangkan potensi diri mahasiswanya. Dewan Perwakilan Mahasiswa Keluarga Mahasiswa Telkom University atau biasa disingkat DPM Kema Tel-U adalah salah satu organisasi mahasiswa di Universitas Telkom yang memiliki beberapa fungsi seperti pengawasan, legislasi, aspirasi, dan anggaran. Diperlukan keterlibatan mahasiswa Universitas Telkom dalam menjalankan keempat fungsi tersebut, dan salah satu cara yang digunakan adalah dengan melakukan kegiatan publikasi terkait berbagai kegiatan yang akan maupun tengah diadakan. Namun, DPM Kema Tel-U belum dapat memaksimalkan website yang justru dianggap sebagai kanal utama dalam kegiatan penyebaran informasi. Untuk menjawab permasalahan tersebut, peneliti akan melakukan studi literatur untuk mendapatkan berbagai teori yang relevan, memodifikasi instrumen WebQual 4.0 yang disesuaikan dengan kebutuhan penelitian, kemudian melakukan penyebaran kuesioner kepada 120 mahasiswa Universitas Telkom. Data-data 
yang terkumpul akan dianalisis menggunakan metode tingkat kesesuaian dan importanceperformance analysis menggunakan aplikasi SPSS versi 25 untuk menjawab permasalahan penelitian. Penelitian ini bertujuan untuk mengetahui tingkat kepuasan pengguna terhadap website DPM Kema Tel-U, serta mengidentifikasi variabel-variabel yang perlu dibenahi dalam rangka meningkatkan kualitas obyek penelitian sesuai dengan prioritasnya. Adapun hasil yang didapat adalah berupa urutan prioritas pembenahan website yang dikelola oleh Dewan Perwakilan Mahasiswa Keluarga Mahasiswa Telkom University, dan sebuah instrumen baru yang didapat dari hasil modifikasi instrumen WebQual 4.0. Penelitian ini dapat menjadi acuan untuk meneliti dan menilai website lainnya yang serupa dengan website DPM Kema Tel-U.

Kata kunci: dewan perwakilan mahasiswa; importance performance analysis; organisasi mahasiswa; situs web; webqual 4.0

\section{PENDAHULUAN}

Perguruan tinggi tidak terlepas dari berbagai kegiatan mahasiswa yang berorientasi pada Tri Dharma Perguruan Tinggi, yakni pendidikan, penelitian, dan pengabdian pada masyarakat. Tri Dharma tersebut tertuang pada berbagai kegiatan mahasiswa, seperti halnya dalam berorganisasi. Universitas Telkom yang memiliki visi untuk menjadi universitas berkelas dunia, telah memiliki beberapa macam organisasi mahasiswa dalam rangka menyalurkan dan mengembangkan potensi diri mahasiswanya. Organisasi-organisasi tersebut di antaranya adalah Dewan Perwakilan Mahasiswa, Badan Eksekutif Mahasiswa, Unit Kegiatan Mahasiswa, Unit Kerohanian Mahasiswa, dan Himpunan Mahasiswa. Kelima macam organisasi tersebut bergerak pada berbagai bidang dan tingkatan yang berbeda, baik dalam lingkup program studi, fakultas, maupun universitas.

Semenjak diresmikannya Universitas Telkom, pada tahun 2014 telah dibentuk Dewan Perwakilan Mahasiswa Keluarga Mahasiswa Telkom University atau biasa disebut DPM Kema Tel-U, sebagai lembaga legislatif mahasiswa tertinggi yang beranggotakan mahasiswa dari tujuh fakultas yang ada pada Universitas Telkom. DPM Kema Tel-U memiliki tugas dalam melaksanakan dan mengawasi Anggaran Dasar, Anggaran Rumah Tangga, Garis Besar Haluan Organisasi, dan juga Rekomendasi Kerja Kema Tel-U ke dalam program kerja DPM Kema Tel-U, untuk menjalankan fungsi pengawasan, legislasi, aspirasi, serta anggaran.

Dalam menjalankan tugas pokok dan fungsinya, DPM Kema Tel-U memerlukan keterlibatan mahasiswa Universitas Telkom. Salah satu hal yang dapat digunakan untuk meningkatkan keterlibatan mahasiswa adalah dengan melakukan publikasi atas berbagai program kerja maupun kegiatan yang akan dan tengah diadakan oleh DPM Kema Tel-U melalui berbagai kanal informasi seperti website dan media sosial yang dikelolanya. Saat ini, DPM Kema Tel-U merasa bahwa sudah mampu mengoptimalkan kegiatan publikasi melalui media sosial dengan melakukan live report, flash report, media partner, dan lain sebagainya. Di lain sisi, DPM Kema Tel-U merasa belum dapat memaksimalkan website yang justru dianggap sebagai kanal utama dalam kegiatan penyebaran informasi.

Seringkali dijumpai dalam berbagai penelitian untuk menilai kualitas dari sebuah website, peneliti menggunakan sebuah instrumen bernama WebQual 4.0 yang menilai tiga buah variabel yakni usability, information quality, dan service interaction quality(Nurhayati \& Febrianti, 2013). Meskipun cukup populer, namun instrumen tersebut seringkali digunakan hanya untuk mengukur kualitas dari website jenis e-commerce, korporat, dan lain sejenisnya. Masih sangat jarang ditemukan penelitian yang menggunakan instrumen WebQual 4.0 tersebut untuk mengukur kualitas website organisasi mahasiswa.

Dalam penelitian ini, peneliti akan membahas mengenai kualitas website DPM Kema Tel-U menggunakan instrumen WebQual 4.0 yang telah dimodifikasi. Penilaian kualitas website tersebut akan diangkat dari perspektif dan harapan mahasiswa Universitas Telkom sebagai target audience utama, dan dilanjutkan dengan menentukan prioritas atau tahapan-tahapan untuk mengatasi kesenjangan antara harapan mahasiswa Universitas Telkom dan kualitas website DPM Kema Tel-U yang menjadi obyek utama dalam penelitian ini. Adapun pada akhirnya, instrumen hasil modifikasi 
yang digunakan dalam penelitian ini dapat diimplementasikan kembali pada penelitian lain dengan obyekpenelitian yang serupa.

Dari fenomena yang tengah terjadi, dapat dirumuskan permasalahan seperti berikut.

1. Apa harapan mahasiswa Universitas Telkom terhadap kualitas website DPM Kema Tel-U?

2. Sudah seberapa baik kualitas website DPM Kema Tel-U menurut perspektif mahasiswa Universitas Telkom?

3. Bagaimana urutan dalam mengatasi kesenjangan antara harapan dan persepsi mahasiswa Universitas Telkom terhadap kualitas website DPM Kema Tel-U?

Penelitian ini diadakan dengan tujuan untuk mengetahui tingkat kepuasan pengguna terhadap website DPM Kema Tel-U dan juga mengidentifikasi variabel-variabel yang perlu dilakukan pembenahan untuk meningkatkan kualitas website yang diteliti, sesuai dengan tingkat urgensinya.

Studi literatur yang perlu dilakukan untuk memperkuat perspektif peneliti dan berguna untuk menganalisis data menggunakan teori dari hasil-hasil penelitian terdahulu. Dengan demikian, peneliti dapat lebih memahami metode riset serta cara pengaplikasiannya dan memahami pemikiran dan apa yang dilakukan oleh peneliti dalam bidang serupa (Soewardikoen, 2013). Studi literatur akan membantu peneliti dalam merumuskan pertanyaan kuesioner penelitian.

\subsection{Website}

Website adalah sebuah lokasi komputer tertentu di internet yang terdiri dari beberapa halaman terkait dan dapat berisi teks, gambar, suara, maupun video (Faizal et al., 2018). Sebuah website memiliki jangkauan yang jauh lebih luas dibandingkan dengan media konvensional seperti surat kabar, televisi, dan lain sebagainya (Darmawan \& Permana, 2013).

\subsection{Usability}

Usability mengacu pada kualitas pengalaman pengguna ketika berinteraksi dengan produk atau sistem, yang termasuk di antaranya adalah website. Usability berbicara tentang efektivitas, efisiensi, dan kepuasan pengguna secara menyeluruh (Usability Testing, 2013). Usability juga dapat diasosiasikan sebagai sebuah kualitas yang berkenaan dengan desain dan nilai kegunaan dari suatu website (Nurhayati \& Febrianti, 2013).

\subsection{Information quality}

Information quality merupakan konsep kualitas dalam penyampaian konten informasi kepada khalayak secara akurat, aktual, dan sesuai (Nurhayati \& Febrianti, 2013).

\subsection{Service interaction quality}

Service interaction quality merupakan tingkat kualitas dari sebuah layanan interaksi yang dirasakan oleh pengguna ketika mereka menjelajah lebih dalam pada suatu website, yang diwujudkan dalam bentuk kepercayaan dan rasa empati (Nurhayati \& Febrianti, 2013).

\subsection{User satisfaction}

User satisfaction dapat didefinisikan sebagai jumlah atau persentase dari keseluruhan pelanggan yang melaporkan pengalamannya terhadap suatu perusahaan, produk, atau layanan, dan dinilai melebihi suatu tingkat kepuasan yang telah ditentukan (Frendy, 2013). Untuk mengukur tingkat user satisfaction pada website, peneliti dapat menggunakan instrumen WebQual 4.0, di mana responden akan diminta untuk menjawab beberapa pertanyaan untuk mengukur kualitas dari suatu website (Nurhayati \& Febrianti, 2013). WebQual 4.0 dirumuskan berdasarkan tiga area keilmuan:

1. Usability from human-computer interaction

2. Information quality

3. Interaction and service quality

Hasil kajian dari ketiga area keilmuan tersebut menghasilkan 23 pertanyaan dalam instrumen WebQual 4.0 yang dapat digunakan sebagai indikator penilaian suatu website, yang dapat dilihat pada Tabel 1. 
Tabel 1. Instrumen webqual 4.0

\begin{tabular}{ll}
\hline Variabel & \\
\hline Usability & 1. I find the site easy to learn to operate \\
& 2. My interaction with the site is clear and understandable \\
& 3. I find the site easy to navigate \\
& 4. I find the site easy to use \\
& 5. The site has an attractive appearance \\
& 6. The design is appropriate to the type of site \\
& 7. The site conveys a sense of competency \\
& 8. The site creates a positive experience for me \\
Information & 9. Provides accurate information \\
Quality & 10. Provides believable information \\
& 11. Provides timely information \\
& 12. Provides relevant information \\
13. Provides easy to understand information \\
14. Provides information at the right level of detail \\
15. Presents the information in an appropriate format \\
Quality & 16. Has a good reputation \\
& 17. It feels safe to complete transactions \\
& 19. My personal information feels secure \\
& 20. Conveys a sense of personalization \\
21. Makes it easy to communicate with the organization \\
22. Ifeel confident that goods/services will be delivered as promised
\end{tabular}

Sumber: Nurhayati \& Febrianti (2013)

Hingga saat ini, instrumen WebQual 4.0 seringkali dimodifikasi dengan menyesuaikan obyek yang akan diteliti, seperti modifikasi untuk menganalisis website pemerintah (Masthori, Nugroho, \& Ferdiana, 2016; Wicaksono, Susanto, \& Winarno, 2012) dan perguruan tinggi (Hafiz, 2017). Meskipun demikian, terlihat bahwa variabel usability, information quality, dan service interaction quality masih tetap hadir dalam instrumen hasil modifikasi tersebut.

Dalam penelitian ini, peneliti membuat asumsi bahwa terdapat kesenjangan antara harapan dan persepsi mahasiswa Universitas Telkom terhadap website DPM Kema Tel-U yang menyebabkan kualitas website tersebut belum dapat dinilai baik, menimbang dari pernyataan DPM Kema Tel-U bahwa belum maksimalnya kegiatan pengelolaan website yang dilakukan selama ini.

\section{METODE}

Berikut ini adalah rerangka atas kegiatan penelitian yang dilakukan.Pada Gambar 1, terlihat bahwa alur penelitian ini dimulai dari kegiatan identifikasi fenomena yang tengah terjadi, perumusan masalah berdasarkan fenomena, melakukan studi pustaka sebagai landasan berpikir, perumusan asumsi, perumusan pertanyaan kuesioner, uji validitas dan reliabilitas kuesioner penelitian, mengumpulkan dan melakukan analisis dari data yang telah didapat, hingga melakukan penarikan kesimpulan dan pemberian saran pada obyek yang diteliti. 


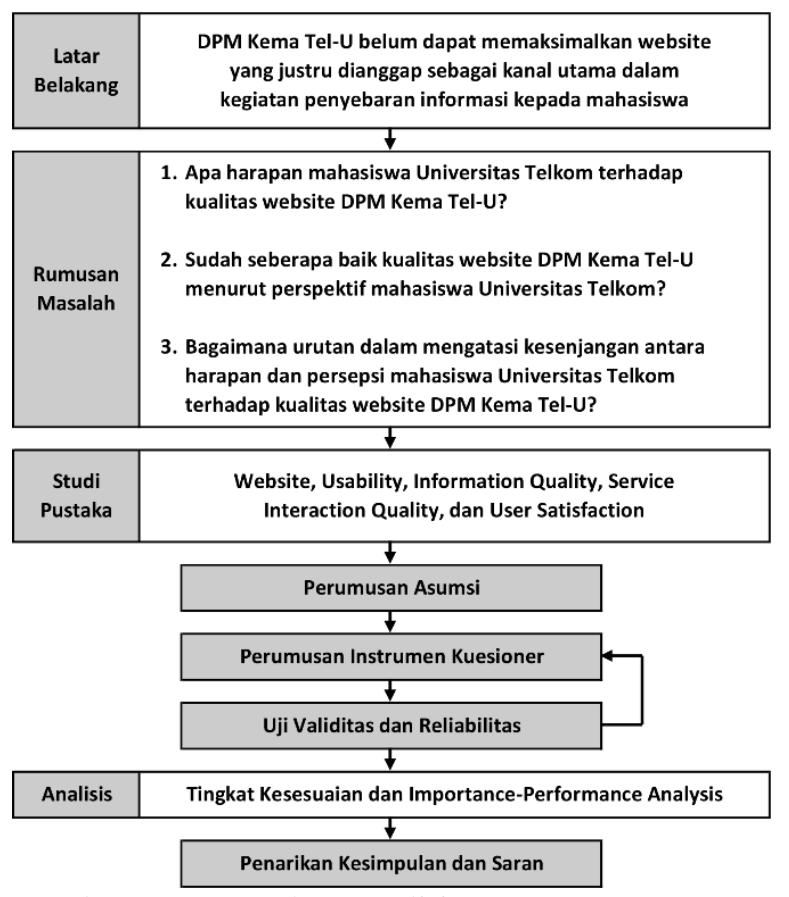

Gambar 1. Rerangka penelitian

Sumber: Olahan peneliti dari berbagai sumber

Dalam merumuskan pertanyaan kuesioner, peneliti akan memodifikasi instrumen WebQual 4.0 yang disesuaikan dengan obyek penelitian, yakni website organisasi mahasiswa yang difungsikan sebagai kanal publikasi informasi. Dengan tanpa menghilangkan variabel-variabel utama dari WebQual 4.0, instrumen yang telah dimodifikasi kemudian diujikan validitas serta reliabilitasnya agar dapat digunakan oleh peneliti lain dalam menguji website yang serupa. Pemilihan metode analisis yang digunakan dalam penelitian ini bertujuan untuk memecahkan permasalahan yang diutarakan, yakni mengidentifikasi harapan pengguna terhadap website, tingkat kualitas website yang diteliti, hingga menentukan cara untuk mengatasi kesenjangan antara harapan dan persepsi pengguna terhadap website.

Populasi adalah jumlah keseluruhan unit yang akan diteliti (Soewardikoen, 2013). Penelitian ini akan ditujukan terhadap mahasiswa Universitas Telkom dengan jumlah populasi sebanyak 30.000 orang. Dari jumlah populasi tersebut, akan digunakan teknik random sampling atau teknik memilih sampel secara acak karena setiap anggota populasi penelitian dianggap homogen (Soewardikoen, 2013).

Untuk mengetahui jumlah sampel minimal yang dibutuhkan dalam penelitian ini, penelitian menggunakan rumus Slovin (Suharsaputra, 2012) sebagai berikut.

Keterangan:

$$
n=\frac{N}{1+N e^{2}}
$$

n: Jumlah sampel

$\mathrm{N}$ : Jumlah populasi

e: Persentase toleransi kesalahan pengambilan sampel yang dapat diterima

Maka: $n=\frac{30.000}{1+30.000(0.1)^{2}}=\frac{30.000}{301}=99.67$

Persentase toleransi kesalahan yang dapat diterima adalah sebesar $10 \%$, dengan mempertimbangkan responden yang homogen. Dengan menggunakan rumus Slovin tersebut, sampel minimal dari penelitian ini adalah sebesar 99.67 atau dapat dibulatkan ke atas menjadi 100 orang mahasiswa Universitas Telkom. 
Mengetahui bahwa website DPM Kema Tel-U merupakan sebuah website yang berfungsi sebagai kanal penyampaian informasi kepada mahasiswa Universitas Telkom, maka penelitian ini menggunakan instrumen WebQual 4.0 yang telah dimodifikasi dengan menghilangkan empat buah indikator dari variabel serviceinteractionquality, seperti di antaranya:

17. It feels safe to complete transactions

19. Creates a sense of personalization

20. Conveys a sense of community

22. I feel confident that goods/services will be delivered as promised

Keempat indikator tersebut dihilangkan karena tidak relevan dengan jenis website DPM Kema Tel-U yang merupakan portal informasi yang digunakan sebagai salah satu media publikasi DPM Kema TelU. Selain itu, variabel user satisfaction dengan indikator "overall view of the website" juga akan dihilangkan dari kuesioner karena variabel tersebut telah terjabarkan di dalam ketiga variabel lainnya. Dengan demikian, peneliti telah merumuskan 18 pertanyaan kuesioner yang disebutkan pada Tabel 2 .

Tabel 2. Pertanyaan kuesioner

\begin{tabular}{ll}
\hline Variabel & \multicolumn{1}{c}{ Indikator } \\
\hline Usability & 1. Mudah untuk mempelajari penggunaan website DPM Kema Tel-U \\
& 2. Interaksi yang terjadi cukup jelas dan dapat dimengerti \\
& 3. Mudah untuk melakukan navigasi pada website DPM Kema Tel-U \\
& 4. Mudah untuk menggunakan website DPM Kema Tel-U \\
& 5. Tampilan website DPM Kema Tel-U menarik perhatian \\
& 6. Desain sesuai dengan jenis website DPM Kema Tel-U \\
& 7. Website telah menggambarkan kompetensi DPM Kema Tel-U \\
8. Muncul pengalaman yang baik setelah menggunakan website DPM Kema Tel-U
\end{tabular}

Information 9. Website memberikan informasi yang akurat

Quality 10. Website memberikan informasi yang dapat dipercaya

11. Website memberikan informasi secara tepat waktu

12. Website memberikan informasi yang relevan

13. Website memberikan informasi yang mudah dimengerti

14. Website memberikan informasi dengan detail yang baik

15. Website memberikan informasi dalam format yang benar

Service 16. Website memiliki reputasi yang baik

Interaction 17. Informasi pribadi Anda akan aman ketika mengakses website DPM Kema Tel-U

Quality 18. Website memudahkan Anda untuk berkomunikasi dengan DPM Kema Tel-U

Sumber: Modifikasi peneliti dari Nurhayati \&Febrianti (2013)

Seluruh pertanyaan tersebut akan diajukan dengan menggunakan skala Likert, yakni sebuah skala pengukuran yang didasarkan pada penjumlahan sikap responden yang berkaitan dengan variabel yang sedang diukur (Sanusi, 2011). Seluruh pertanyaan kuesioner akan disajikan dengan empat gradasi pilihan jawaban "sangat tidak setuju", "tidak setuju", "setuju", dan "sangat setuju".

\section{HASIL DAN PEMBAHASAN}

\subsection{Uji validitas}

Uji validitas merupakan pengujian untuk mengetahui sejauh mana sebuah instrumen mampu mengukur variabel yang ingin diukur (Wibowo, 2012). Kuesioner yang telah dirancangdiujikan kepada 30 orang mahasiswa Universitas Telkom yang merupakan target audience dari website DPM Kema Tel-U. 
Tabel 3. Hasil uji validitas

\begin{tabular}{lll}
\hline No. & $\begin{array}{l}\text { Nilai R } \\
\text { Pertanyaan }\end{array}$ & Keterangan \\
\hline 1 & 0.922 & Valid \\
2 & 0.861 & Valid \\
3 & 0.886 & Valid \\
4 & 0.922 & Valid \\
5 & 0.845 & Valid \\
6 & 0.845 & Valid \\
7 & 0.699 & Valid \\
8 & 0.699 & Valid \\
9 & 0.886 & Valid \\
10 & 0.886 & Valid \\
11 & 0.726 & Valid \\
12 & 0.886 & Valid \\
13 & 0.922 & Valid \\
14 & 0.922 & Valid \\
15 & 0.852 & Valid \\
16 & 0.886 & Valid \\
17 & 0.608 & Valid \\
18 & 0.886 & Valid \\
\hline Sumb: Olan & peneli &
\end{tabular}

Sumber: Olahan peneliti

Dari pengujian validitas kuesioner yang telah dilakukan menggunakan aplikasi SPSS versi 25 , terlihat bahwa 18 pertanyaan yang dirumuskan ke dalam kuesioner seluruhnya bersifat valid karena nilai $\mathrm{R}$ Pearson dari setiap pertanyaan memiliki nilai lebih besar dari yang tertera pada tabel R, yakni sebesar 0.361 .

\subsection{Uji reliabilitas}

Uji reliabilitas merupakan pengujian untuk mengetahui sejauh mana suatu hasil pengukuran relatif konsisten apabila pengukuran tersebut diulangi lebih dari satu kali (Wibowo, 2012). Peneliti melakukan uji reliabilitas dengan menggunakan aplikasi SPSS versi 25 dan didapat nilai koefisien reliabilitas sebesar 0.961. Adapun besarnya koefisien reliabilitas minimal yang harus dipenuhi oleh suatu alat ukur adalah 0.7(Sekaran \& Bougie, 2013). Mengacu pada hal tersebut, dapat disimpulkan bahwa kuesioner yang dirancang peneliti sudah reliabel dan dapat digunakan untuk mengumpulkan data yang diperlukan dalam penelitian ini.

\subsection{Tingkat kesesuaian}

Tingkat kesesuaian yang dimaksud dalam penelitian ini adalahsebuah metode dengan membandingkan skor persepsi dengan skor yangdiharapkan oleh responden (Anggraeni, Deoranto, \& Ikasari, 2015).Adapun hasil dari perbandingan tersebut akan menunjukkan indikator yang memerlukan pembenahan pada website DPM Kema Tel-U.

\subsection{Importance-performance analysis}

\begin{tabular}{c|c|c} 
& $\begin{array}{c}\text { Kuadran 1 } \\
\text { Butuh perbaikan }\end{array}$ & $\begin{array}{c}\text { Kuadran 2 } \\
\text { Kualitas baik }\end{array}$ \\
\cline { 2 - 3 } & $\begin{array}{c}\text { Kuadran 3 } \\
\text { Prioritas rendah }\end{array}$ & $\begin{array}{c}\text { Kuadran 4 } \\
\text { Berlebihan }\end{array}$ \\
\hline \multicolumn{2}{|c}{ Persepsi }
\end{tabular}

Gambar 2. Contoh diagram IPA

Sumber: Modifikasi peneliti dari Wong, Hideki, \& George (2011) 
Importance-performance analysis atau disingkat IPA merupakan cara untuk melihat respon konsumen terhadap kualitas produk atau layanan yang diukur berdasarkan persepsi dan harapan dari produk atau layanan tersebut, dan diplotkan pada diagram kartesius (Puspitasari, Suliantoro, \& Kusumawardhani, 2010). Pada diagram tersebut terdapat empat kuadran, yakni kuadran 1 yang berisi indikator yang memerlukan prioritas utama untuk dilakukan pembenahan, kuadran 2 yang berisi indikator yang harus dipertahankan prestasinya, kuadran 3 yang berisi indikator dengan prioritas rendah, serta kuadran 4 yang berisi indikator dengan kualitas yang berlebihan(Wong et al., 2011).

18 indikator yang telah dinilai oleh para responden penelitian selanjutnya akan dikelompokkan dan dimasukan ke dalam keempat kuadran tersebut, dengan memperhatikan kriteria-kriteria pada Tabel 4.

Tabel 4. Kategorisasi kuadran diagram IPA

\begin{tabular}{lcc}
\hline Kuadran & Persepsi & Harapan \\
\hline 1 & < rata-rata persepsi & > rata-rata harapan \\
2 & > rata-rata persepsi & > rata-rata harapan \\
3 & < rata-rata persepsi & < rata-rata harapan \\
4 & > rata-rata persepsi & < rata-rata harapan \\
\hline
\end{tabular}

Sumber: Modifikasi peneliti dari Wong et al.(2011)

Untuk mempermudah proses visualisasi dan analisis, peneliti akan menggunakan SPSS versi 25 untuk menggambarkan diagram IPA tersebut.

3.5 Karakteristik eesponden

Peneliti telah melakukan penyebaran kuesioner kepada 120 orang mahasiswa Universitas Telkom dari seluruh fakultas, dengan karakteristik seperti yang tergambarkan pada Tabel 5.

Tabel 5. Karakteristik responden

\begin{tabular}{|c|c|c|}
\hline Keterangan & Jumlah & Persentase \\
\hline \multicolumn{3}{|l|}{ Jenis kelamin } \\
\hline - Laki-laki & 64 orang & $53.33 \%$ \\
\hline - Perempuan & 56 orang & $46.67 \%$ \\
\hline \multicolumn{3}{|l|}{ Fakultas } \\
\hline - Teknik Elektro & 12 orang & $10 \%$ \\
\hline - Rekayasa Industri & 6 orang & $5 \%$ \\
\hline - Informatika & 39 orang & $32.5 \%$ \\
\hline - Ekonomi dan Bisnis & 36 orang & $30 \%$ \\
\hline - Komunikasi dan Bisnis & 3 orang & $2.5 \%$ \\
\hline - Industri Kreatif & 18 orang & $15 \%$ \\
\hline - Ilmu Terapan & 6 orang & $5 \%$ \\
\hline \multicolumn{3}{|l|}{ Angkatan } \\
\hline - 2014 dan sebelumnya & 18 orang & $15 \%$ \\
\hline • 2015 & 42 orang & $35 \%$ \\
\hline • 2016 & 12 orang & $10 \%$ \\
\hline • 2017 & 30 orang & $25 \%$ \\
\hline • 2018 & 18 orang & $15 \%$ \\
\hline \multicolumn{3}{|l|}{$\begin{array}{l}\text { Perangkat yang sering } \\
\text { digunakan untuk mengakses } \\
\text { internet }\end{array}$} \\
\hline - Desktop & 15 orang & $12.5 \%$ \\
\hline - Mobile & 28 orang & $23.33 \%$ \\
\hline - Keduanya & 77 orang & $64.17 \%$ \\
\hline $\begin{array}{l}\text { Pernah mengakses website } \\
\text { DPM Kema Tel-U }\end{array}$ & & \\
\hline
\end{tabular}


Jurnal Manajemen Maranatha ø Vol. 19 Nomor 1, November (2019)

\begin{tabular}{lll}
\hline - Pernah & 60 orang & $50 \%$ \\
- Tidak pernah & 54 orang & $45 \%$ \\
- Ragu-ragu & 6 orang & $5 \%$ \\
\hline
\end{tabular}

Sumber: Olahan peneliti

Dari data tersebut, dapat dilihat bahwa 77 orang responden mengakses internet melalui perangkat desktop maupun mobile dan 50\% dari total responden pernah mengakses website DPM Kema Tel-U. Data tersebut menunjukkan bahwa tingkat ketersebaran website dapat terus ditingkatkan kembali untuk memaksimalkan ketersebaran informasi yang dikelola oleh DPM Kema Tel-U, dengan merancang sebuah tampilan website yang dapat diakses dengan mudah baik melalui perangkat desktop maupun mobile.

3.6 Hasil penelitian dan pembahasan

Dari hasil kuesioner yang telah dibagikan kepada 120 orang responden, dapat diukur tingkat kesesuaian yang telah tergambarkan pada Tabel 6 .

Tabel 6. Hasil pengukuran tingkat kesesuaian

\begin{tabular}{llll}
\hline Indikator & Persepsi & Harapan & Kesesuaian \\
\hline 1 & 406 & 447 & $90.83 \%$ \\
2 & 403 & 453 & $88.96 \%$ \\
3 & 414 & 441 & $93.88 \%$ \\
4 & 415 & 459 & $90.41 \%$ \\
5 & 369 & 447 & $82.55 \%$ \\
6 & 394 & 446 & $88.34 \%$ \\
7 & 391 & 424 & $92.22 \%$ \\
8 & 382 & 425 & $89.88 \%$ \\
9 & 425 & 465 & $91.40 \%$ \\
10 & 415 & 462 & $89.83 \%$ \\
11 & 394 & 446 & $88.34 \%$ \\
12 & 412 & 459 & $89.76 \%$ \\
13 & 406 & 459 & $88.45 \%$ \\
14 & 413 & 447 & $92.39 \%$ \\
15 & 413 & 447 & $92.39 \%$ \\
16 & 406 & 449 & $90.42 \%$ \\
17 & 399 & 459 & $86.93 \%$ \\
18 & 389 & 459 & $84.75 \%$ \\
\hline Rata-rata & 381.37 & 426 & $89.52 \%$ \\
\hline Sur & Olan penc
\end{tabular}

Sumber: Olahan peneliti

Dari Tabel 6, terlihat bahwa 18 indikator yang diujikan perlu dilakukan pembenahan karena tingkat kesesuaian tidak ada yang mencapai $100 \%$ atau lebih. Setelah mengetahui jumlah rerata persepsi dan harapan responden, data yang ada kemudian dikategorisasikan seperti yang terlihat pada Tabel 7.

Tabel 7. Kategorisasi hasil penelitian

\begin{tabular}{llll}
\hline Indikator & Persepsi & Harapan & Kuadran \\
\hline 1 & 406 & 447 & 4 \\
2 & 403 & 453 & 2 \\
3 & 414 & 441 & 4 \\
4 & 415 & 459 & 2 \\
5 & 369 & 447 & 3 \\
6 & 394 & 446 & 3 \\
7 & 391 & 424 & 3 \\
8 & 382 & 425 & 3 \\
9 & 425 & 465 & 2 \\
10 & 415 & 462 & 2 \\
\hline
\end{tabular}




\begin{tabular}{llll}
\hline 11 & 394 & 446 & 3 \\
12 & 412 & 459 & 2 \\
13 & 406 & 459 & 2 \\
14 & 413 & 447 & 4 \\
15 & 413 & 447 & 4 \\
16 & 406 & 449 & 4 \\
17 & 399 & 459 & 1 \\
18 & 389 & 459 & 1 \\
\hline
\end{tabular}

Sumber: Olahan peneliti

Hasil pada Tabel 7 kemudian akan digambarkan ke dalam bentuk diagram kartesius seperti yang terlihat pada Gambar 3.

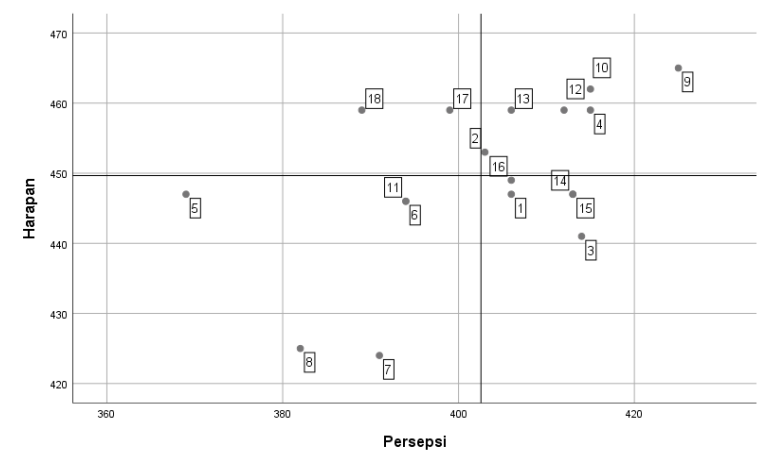

Gambar 3. Diagram IPA hasil analisis

Sumber: Olahan peneliti dari SPSS

Dari diagram tersebut dapat diketahui bahwa ada dua indikator yang memerlukan pembenahan dengan segera, yakni keamanan informasi pengguna ketika mengakses website DPM Kema Tel-U dan kemudahan pengguna untuk berkomunikasi dengan DPM Kema Tel-U melalui website tersebut.

Selain itu, ada enam indikator yang dinilai sudah baik oleh responden, seperti interaksi yang terjadi cukup jelas dan dapat dimengerti, kemudahan untuk menggunakan website DPM Kema Tel-U, serta tersedianya informasi yang akurat, dapat dipercaya, relevan, dan mudah dimengerti.Di sisi lain, ada lima indikator yang dinilai memiliki nilai kepuasan berlebih seperti kemudahan untuk mempelajari dan melakukan navigasi pada website DPM Kema Tel-U, format dan detail yang baik pada informasi yang disajikan, serta reputasi yang baik pada website tersebut. Sementara, kelima indikator lainnya dinilai memiliki prioritas rendah untuk dilakukan pembenahan.

Kemudian untuk menentukan urutan prioritas per indikator, peneliti akan melihat dari besarnya persentase pada Tabel 8. Dari hasil tersebut, peneliti mengurutkan prioritas indikator secara berurutan dari yang terpenting adalah indikator 5, 18, 17, 6, 11, 13, 2, 12, 10, 8, 4, 16, 1, 9, 7, 14, 15, dan 3 . Urutan-urutan tersebut telah dijabarkan dalam Tabel 8.

Tabel 8. Pengurutan prioritas tiap indikator

\begin{tabular}{lll}
\hline Prioritas & Indikator & Kesesuaian \\
\hline 1 & 5 & $82.55 \%$ \\
2 & 18 & $84.75 \%$ \\
3 & 17 & $86.93 \%$ \\
4 & 6 & $88.34 \%$ \\
5 & 11 & $88.34 \%$ \\
6 & 13 & $88.45 \%$ \\
7 & 2 & $88.96 \%$ \\
8 & 12 & $89.76 \%$ \\
9 & 10 & $89.83 \%$ \\
10 & 8 & $89.88 \%$ \\
11 & 4 & $90.41 \%$ \\
12 & 16 & $90.42 \%$ \\
\hline
\end{tabular}




\begin{tabular}{lll}
\hline 13 & 1 & $90.83 \%$ \\
14 & 9 & $91.40 \%$ \\
15 & 7 & $92.22 \%$ \\
16 & 14 & $92.39 \%$ \\
17 & 15 & $92.39 \%$ \\
18 & 3 & $93.88 \%$ \\
\hline
\end{tabular}

Sumber: Olahan peneliti

Dengan memperhatikan urutan tersebut, maka pengelola website dapat menentukan urutan prioritas pengerjaan dalam proses pembenahan websiteDPM Kema Tel-U.

Dari kegiatan penelitian yang dilakukan, telah terbentuk sebuah instrumen baru yang dikhususkan untuk menilai kualitas dari sebuah website organisasi mahasiswa yang difungsikan sebagai kanal publikasi informasi. Tahapan dalam penelitian seperti pembentukan instrumen, pengujian validitas dan reliabilitas, pengukuran tingkat kesesuaian, dan pengurutan prioritas dari setiap indikator yang ada dapat menjadi sebuah acuan bagi peneliti-peneliti lain, ketika akan melakukan penelitian terhadap obyek yang serupa dengan yang dibahas dalam penelitian ini.

\section{SIMPULAN DAN SARAN}

Dari penelitian ini, dapat ditarik simpulan bahwa ada 18 indikator yang menjadi harapan para pengguna website DPM Kema Tel-U dan teridentifikasi urutan prioritas dari setiap indikator sebagai acuan dalam melakukan pembenahan website tersebut. Secara umum, penelitian ini sudah dapat mengidentifikasi hal-hal yang diinginkan dan dipersepsikan pengguna terhadap website DPM Kema Tel-U, serta bagaimana urutan dalam melakukan pembenahan terhadap website tersebut sesuai tingkat prioritasnya. Selain itu, instrumen yang digunakan dalam penelitian ini dapat juga diterapkan pada penelitian lain yang serupa.

Adapun beberapa saran yang ditujukan kepada DPM Kema Tel-U untuk membenahi website yang dikelolanya, seperti di antaranya menambahkan fitur atau informasi yang dapat memudahkan pengguna untuk berkomunikasi dengan DPM Kema Tel-U pada website; membenahi dan meyakinkan pengguna bahwa informasi pribadi pengguna websiteakan aman ketika mereka mengunjungi website DPM Kema Tel-U; mengurangi fokus terhadap indikator-indikator yang terdapat pada kuadran 4 dan lebih memperhatikan dan membenahi indikator-indikator pada kuadran 1; melakukan penilaian dan pembenahan secara berkala agar website selalu mendapat kualitas yang diinginkan oleh para penggunanya; serta mengarahkan mahasiswa yang mengikuti akun-akun media sosial DPM Kema TelU untuk mengakses website dengan tujuan meningkatkan jumlah pengunjung.

Penelitian ini juga dapat dikembangkan kembali dengan melakukan penambahan variabel dalam instrumen, serta dengan melakukan perbandingan dengan beberapa website serupa untuk lebih memperjelas variabel-variabel yang memerlukan evaluasi dari obyek penelitian. Selain itu, dapat dilakukan pengukuran sebelum dan setelah dilakukan optimalisasi terhadap website, untuk membandingkan pengaruh dari dilakukannya kegiatan analisis tersebut.

Beberapa keterbatasan dalam kegiatan penelitian ini adalah minimnya inisiatif mahasiswa untuk berperan sebagai responden sehingga memengaruhi waktu yang dibutuhkan peneliti untuk mendapatkan data-data yang akan dianalisis, serta peneliti tidak dapat mengontrol jawaban responden secara langsung, memungkinkan responden untuk tidak menjawab pertanyaan kuesioner secara obyektif.

\section{ACKNOWLDEGEMENTS}

Terima kasih yang sebesar-besarnya saya ucapkan kepada seluruh pihak, khususnya anggota Dewan Perwakilan Mahasiswa Universitas Telkom dan mahasiswa Universitas Telkom yang telah membantu dalam terealisasinya penelitian ini. 


\section{REFERENSI}

Anggraeni, L.D., Deoranto, P., \& Ikasari, D.M. (2015). Analisis persepsi konsumen menggunakan metode Importance Performance Analysis dan Customer Satisfaction Index. Industria: Jurnal Teknologi dan Manajemen Agroindustri, 4(2), 74-81. Diperoleh dari https://industria.ub.ac.id/index.php/industri/article/view/179

Darmawan, D. \& Permana, D.H. (2013). Desain dan pemrograman website. Bandung: PT Remaja Rosdakarya

Faizal, M., Abdillah, M.F., Dea A.S.I.M.S., Setiadi, W., Octavia, D., Suhendari, W., \& Soewardikoen, D.W. (2018). Penggunaan website portal berita sebagai media informasi untuk mahasiswa. Jurnal Bahasa Rupa, 2(1), 34-42. Diperoleh dari https://doi.org/10.31598/bahasarupa.v2i1.217

Frendy, J.S. (2013). The Impact of perceived value on customer satisfaction and repurchase intention of Blackberry users in Manado. Jurnal EMBA: Jurnal Riset Ekonomi, Manajemen, Bisnis dan Akuntansi, 1(4), 1650-1658. Diperoleh dari https://ejournal.unsrat.ac.id/index.php/emba/article/view/3344

Hafiz, A. (2017). Mengukur kualitas website dengan pendekatan WebQual 4.0 modifikasi. Prosiding Seminar Nasional Darmajaya, l(1), 443-457. Diperoleh dari https://jurnal.darmajaya.ac.id/index.php/PSND/article/view/783

Masthori, A., Nugroho, H.A., \& Ferdiana, R. (2016). Penggunaan metode WebQual modifikasi dalam evaluasi kualitas layanan website pemerintah daerah. Pekommas, 1(1), 57-68. Diperoleh dari https://jurnal.kominfo.go.id/index.php/pekommas/article/view/2010106

Nurhayati \& Febrianti, M.S. (2013). Indonesian Puslit (Centre of IT solution) website analysis using Webqual for measuring website quality. International Conference on Engineering and Technology Development (ICETD), 2nd ICETD, 297-306. Diperoleh dari http://artikel.ubl.ac.id/index.php/icetd/article/view/157

Puspitasari, N.B., Suliantoro, H., \& Kusumawardhani, L. (2010). Analisis kualitas pelayanan dengan menggunakan integrasi Importance Performance Analysis (IPA) dan Model Kano (Studi Kasus di PT. Perusahaan Air Minum Lyonnaise Jaya Jakarta). J@ Ti Undip: Jurnal Teknik Industri, 5(3), $185-198$

Sanusi, A. (2011). Metodologi penelitian bisnis. Jakarta: Salemba Empat

Sekaran, U.\& Bougie, R. (2013). Research methods for business: A skill-building approach (6th ed.). New York: Wiley

Soewardikoen, D.W. (2013). Metodologi penelitian visual, dari seminar ke tugas akhir. Bandung: Dinamika Komunika

Suharsaputra, U. (2012). Metode penelitian kuantitatif, kualitatif, dan tindakan. Bandung: PT Revika Aditama

Usability.gov. (2013). Usability testing. Diperoleh dari https://www.usability.gov/how-to-andtools/methods/usability-testing.html

Wibowo, A.E. (2012). Aplikasi praktis SPSS dalam penelitian. Bandung: Gave Media

Wicaksono, B.L., Susanto, A., \& Winarno, W. (2012). Evaluasi kualitas layanan website Pusdiklat BPK RI menggunakan Metode WebQual Modifikasian dan Importance Performance Analysis. MEDIA, 19(1), 21-34. Diperoleh dari http://publikasi.dinus.ac.id/index.php/media/article/view/893

Wong, M.S., Hideki, N., \& George, P. (2011). The use of Importance-Performance Analysis (IPA) in evaluating Japan's e-government services. Journal of Theoretical and Applied Electronic Commerce Research, 6(2), 17-30. Diperoleh dari https://scielo.conicyt.cl/scielo.php?pid=S0718$18762011000200003 \&$ script $=$ sci_arttext 